\title{
Interactive Virtual Reality For Fun Mathematics Learning With Deep Understanding At SMP Swasta Ar-Rahman Percut
}

\author{
Herman Mawengkang ${ }^{1}$, Syahril Efendi ${ }^{2}$, and Muliawan Firdaus ${ }^{3}$ \\ ${ }^{1}$ Department of Mathemtics, Faculty of Mathematics and Science, University of Sumatera Utara, J1. Dr. T. \\ Mansur No. 9, Medan, 20155, Indonesia \\ ${ }^{2}$ Department of Computer Science, Faculty of Computer Science and Information Technology, University of \\ University of Sumatera Utara, J1. Dr. T. Mansur No. 9, Medan, 20155, Indonesia \\ ${ }^{3}$ Graduate School of Mathemtics, Faculty of Mathematics and Science, University of Sumatera Utara, Jl. Dr. \\ T. Mansur No. 9, Medan, 20155, Indonesia \\ E-mail: hmawengkang@yahoo.com

\begin{abstract}
Article history:
Received: Jul 20, 2021

Revised: Aug 15, 2021

Accepted: Oct 06, 2021

Keywords:

Virtual Reality;

Mathematics Learning;

Junior High School.
\end{abstract} \\ ART I CLE INFO

\section{ABSTRACT}


Answering these complaints, the school added several tasks so that students focus on learning activities. However, these additional assignments are still ignored, even causing new complaints from diligent students who really want to do assignments. From interviews with several students, it was revealed that their strong tendency to play smartphones during learning, especially learning mathematics, was not only caused by their difficulty in understanding concepts but also caused by boring and unpleasant learning. No wonder their motivation to use smartphones is much greater than their motivation to study. If this problem is not addressed immediately, the quality of the teaching and learning process will deteriorate which has a direct impact on student learning outcomes. Thus, SMP Swasta Ar-Rahman Percut needs a solution that can not only solve this problem in a short time but also a solution that allows it to be implemented.

\section{Methods}

The implementation method refers to the Learn-Teach-Evaluate-Acknowledge method proposed by Buckenmeyer et al. [2] with several modifications made through the addition of a Fostering phase for the continuation of activities and the adjustment of each phase to the principles of adult learning. Programs that focus on experiential learning and self-motivation are intended to encourage participants and instructors to actively participate [3]. The participants in this activity were three mathematics teachers at SMP Swasta ArRahman Percut.

\section{Results}

The partnership program is carried out face-to-face by implementing strict health protocols. The description of the implementation of activities which includes the stages of Learn, Teach, Evaluate, Acknowledge, and Fostering is described as follows.

\subsection{Learn}

This stage begins with a teaching experience sharing session that focuses on the learning design process. This session involved three resource persons who delivered material on the role of technology in learning, fun learning for junior high school students, and learning with a depth of understanding (Figure 1).

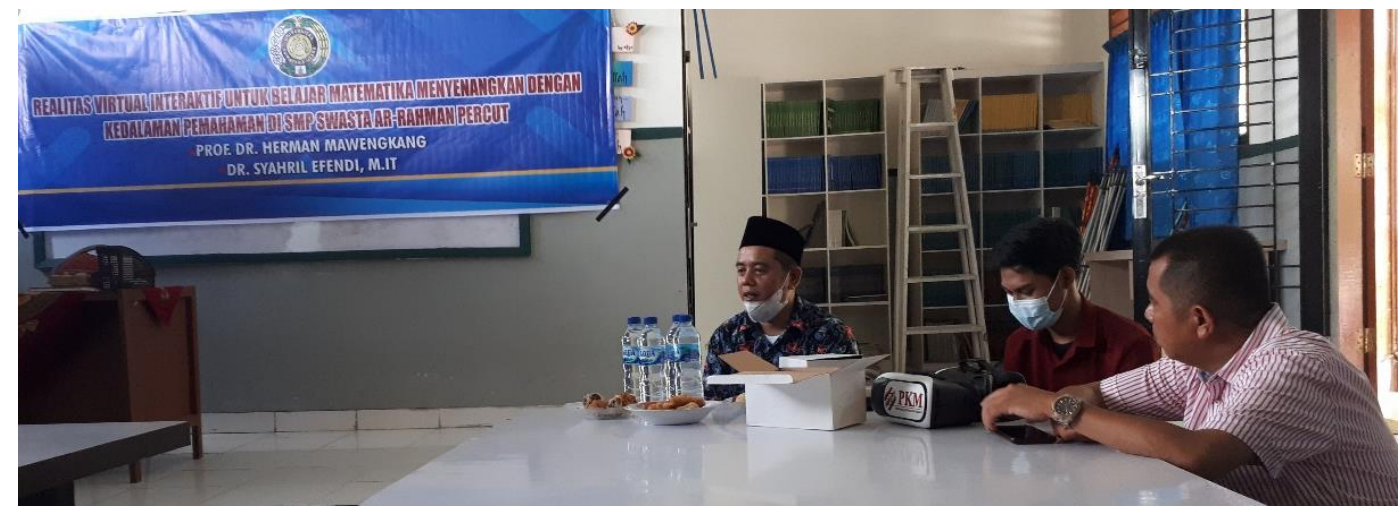

Figure 1. Teaching experience sharing session

The activity continued with a workshop session on the development of interactive VR using OpenSpace3D (Figure 2). This software is a free and open-source platform, designed to create virtual and augmented-reality applications which can be downloaded from https://www.openspace3d.com/.

\subsection{Teach}

Accompanied by an instructor, participants teach with interactive VR they designed and developed previously. Instructional design refers to the stages proposed by Firdaus, et al. [4] and teaching materials proposed by Darari \& Firdaus [5] for online interactive learning. During the activity, the instructor reviews the teaching carried out by the participants and the interactive VR developed by the participants to provide opinions for improvement (Figure 3). 


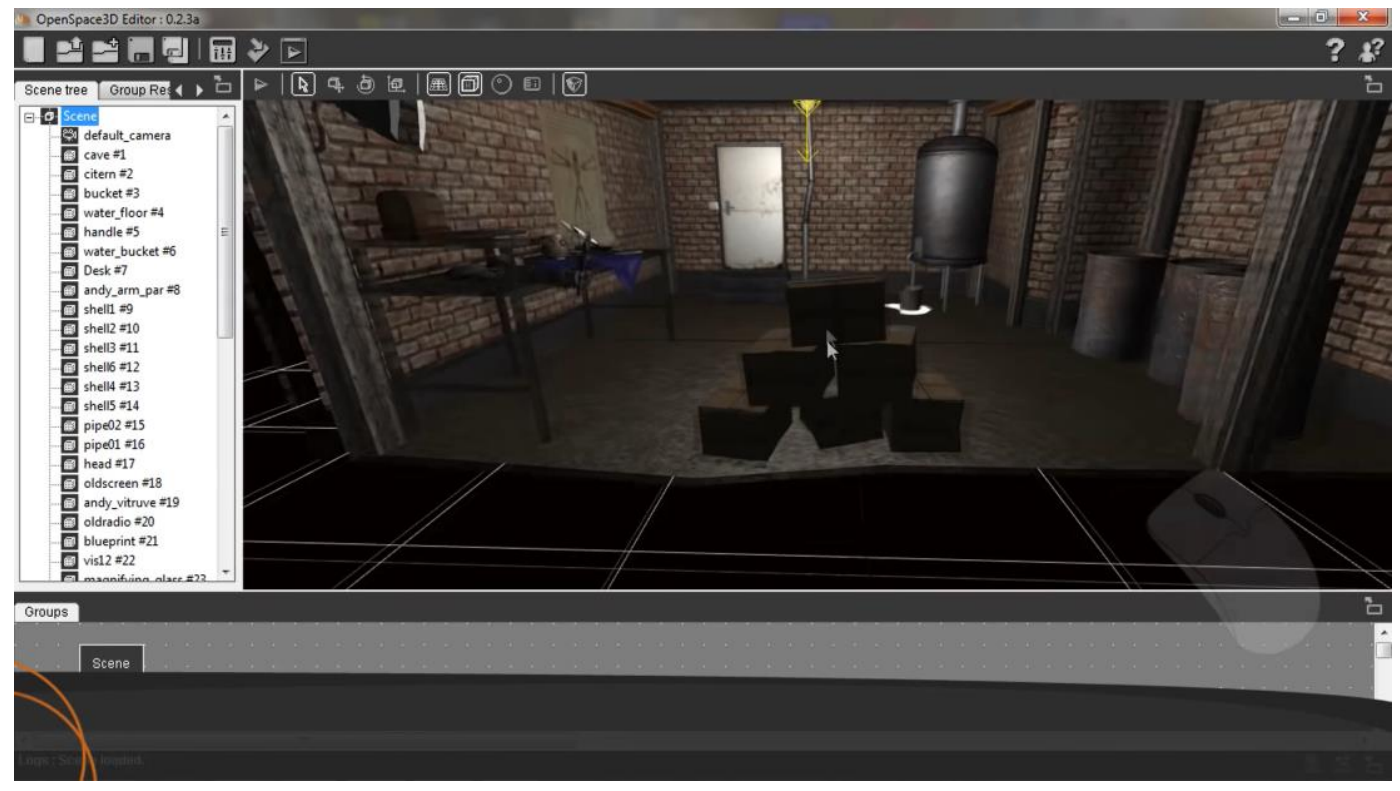

Figure 2. OpenSpace3D

\subsection{Evaluate}

The evaluation stage was carried out on participants teaching with interactive VR and the level of student success in the teaching practice. The assessment of teaching practice used an instrument adapted from Safitri \& Sontani [6] consists of eight aspects of measurement: opening learning, explaining, closing learning, asking questions, giving reinforcement, doing variations, conducting demonstrations, and using interactive VR. The results showed that the ability of participants in carrying out learning practices was in a good category.

The level of student success in teaching practice was assessed using an instrument developed previously with reference to the online formative assessment suggested by Mukhtar et al. [7]. The results showed that student learning outcomes had reached $80 \%$ of the minimum completeness criteria (according to the provisions of SMP Swasta Ar-Rahman Percut) both classically and individually.

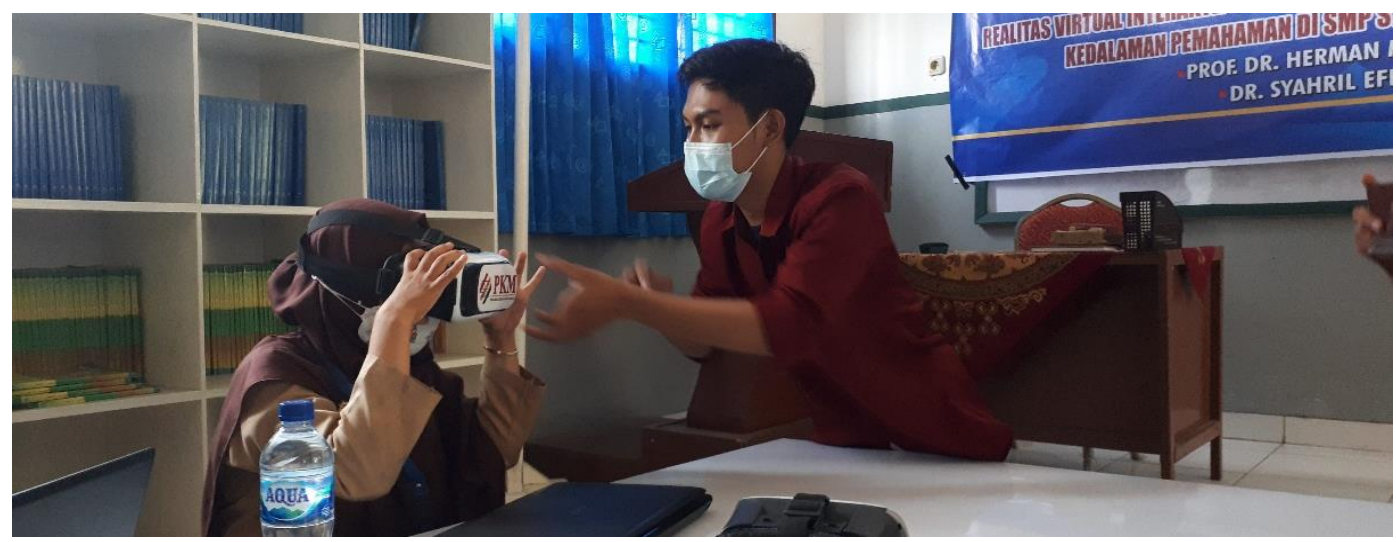

Figure. 3. Mentoring the participants

\subsection{Acknowledgment}

In this stage, a graduation certificate was given to participants who were declared to have passed based on the results of the evaluation of the learning implementation. This stage involves participants who pass as instructors (peers) in the process of improving the learning of other participants who have not passed. 


\subsection{Fostering}

This stage was aimed at ensuring the sustainability of the activity. The activity plan consists of meeting with participants every four months, creating and distributing discussion guides for the meetings, and reviewing the results and implementation of the meetings annually for continuous improvement.

\section{Conclusion}

It should be the main concern that current junior high school students are the millennial generation, the generation of the digital era, and social networks, whose lives are very close to technology. Adjustment of the education system is a big challenge for the government, especially educators who must be addressed appropriately in order to meet the learning needs of students. Therefore, the integration of digital media through smartphones in learning is an important strategy to consider in an effort to meet the learning needs of students who generally have a strong preference for things related to technology.

The current availability of smartphones with increased usability, internet connectivity, data processing power, and accessibility at scale allows the use of VR applications on mobile devices for use in learning mathematics. Virtual reality applications that combine 3-D virtual objects with real 3-D environments and appear together in real-time allow students to see real objects interact with virtual objects superimposed on them so that students' understanding of 3-D objects is believed to be enhanced in a more comprehensive way of experience. Finally, this partnership program had shown that the learning experience created through this application which is the same as the experience in playing games on mobile devices is believed to make learning mathematics more enjoyable.

\section{Acknowledgment}

This partnership program and publication of the results have been supported by grants from the University of Sumatera Utara, Indonesia. Support from Zainuddin Hasibuan, Headmaster of SMP Swasta Ar-Rahman Percut, is also greatly acknowledged.

\section{References}

[1] APJII, Laporan Survei Internet APJII 2019 - 2020 [Q2], 2020, retrieved September 29, 2020.

[2] J. Buckenmeyer, E. Hixon, C. Barczyk, \& L. Feldman, "Does Participation in a Faculty Distance Education Mentoring Program Comprehensively Improve Teaching Methods?," International Journal on E-Learning, vol. 12, no. 12, pp. 139-152. 2013.

[3] J. Walker, "Shame and Transformation in the Theory and Practice of Adult Learning and Education," Journal of Transformative Education, vol. 15, no. 4, pp. 357-374. 2017.

[4] M. Firdaus, Mukhtar, M.B. Darari, \& Z. Azis, "Designing Interactive Videos in Online Multivariable Calculus Course to Support Student's Critical Thinking," Journal of Physics: Conference Series, 1819, 012057. 2021.

[5] M.B. Darari \& M. Firdaus, "Development of Teaching Materials Based 'Activity or Resources' At Sipda Unimed to Enhance Students Learning Behavior," Journal of Physics: Conference Series, 1462, 012022. 2020.

[6] E. Safitri \& U.T. Sontani, "Keterampilan mengajar guru dan motivasi belajar siswa sebagai determinan terhadap hasil belajar," Jurnal Pendidikan Manajemen Perkantoran, vol. 1, no. 1, pp. 144-153. 2016.

[7] Mukhtar, Mulyono, \& M. Firdaus, "Enhancing Students Multivariable Calculus Learning Through Online Formative Feedback," Journal of Physics: Conference Series, 1819, 012058. 2021. 